\author{
Prof. dr Alpar Lošonc* \\ Prof. dr Sonja Bunčićc* \\ Prof. dr Andrea Ivanišević ${ }^{* * *}$
}

\title{
ORDOLIBERAL ARTICULATION OF LAW-ECONOMY COMPLEX
}

\begin{abstract}
Various orientations regarding the relationship between law and economics have emerged in recent decades. However, it should be remembered that German ordoliberalism has already formed a definite and striking orientation regarding the aforementioned relationship between law and economics. Also, ordoliberalism can be seen as the ancestor when it comes to the treatment of the aforementioned relationship. This paper intends to follow ordoliberal conceptualization in the field of law and it consists of three parts. The first part describes briefly the emergence of ordoliberalism and presents the reasons for the influence of ordoliberalism on today's European self-thematization. The second part attempts to show that law is understood as a constituent orientation with respect to the order, a key point of the ordoliberal project, and it explains the meaning of economic constitutionalism. The third part analyzes the importance of competition in the creation of order and it questions how ordoliberalism treats the relation between law and economics, especially in the domain of competition law. The same section explores the issue of defending the identity of ordoliberalism in the context of overall legal and economic dynamics.
\end{abstract}

Key words: ordoliberalism, law and economics, crisis, constitutionalization, economization.

\section{A Short Genesis of the Orientation That (Relatively) Suddenly Became Relevant Again}

Ordoliberalism, which has long been a more exotic (German) orientation, has come into the limelight of various disciplines. We just need to look at some recently published works that report on the intensity and

\footnotetext{
* University of Novi Sad, Faculty of Technical Sciences, e-mail: alpar@uns.ac.rs

** University of Novi Sad, Faculty of Technical Sciences, e-mail: sonja.buncic@gmail.com

*** University of Novi Sad, Faculty of Technical Sciences, e-mail: andrei@uns.ac.rs
} 
heterogeneity of the present acceptance. ${ }^{1}$ Reasons for growing acceptance can be found in different domains: we will try to point to some of them, but first and foremost, we respect legal, that is, legal-economic discourse. ${ }^{2}$ It is important to note that more systematic international acceptance of ordoliberalism began in the last decade of the twentieth century when a jurist interested in the law of competition initiated and articulated it. ${ }^{3}$ Now, however, in the midst of expansive acceptance of ordoliberalism, there is justified lamentation over the fact that law remained in the shadow of the said acceptance, and that the "ordering function of law" (Joerges) did not gain the significance it deserves. ${ }^{4}$

The narrative about ordoliberalism should begin in the Weimar period of Germany. ${ }^{5}$ In fact, ordoliberalism is essentially a primordial kind of replica on the explosion of crisis processes in the said period, as well as an expression of liberalism mutation. Classical forms of liberalism ("paleo-liberalism") are described as tragically inadequate to save freedom from the assault of its opponents. A group of jurists and economists (Franz Böhm, Hans Großmann Doerth, Walter Eucken, Alfred Müller-Armack, Leonhard Miksch, Alexander Rüstow, etc.) converge on the reconceptualization of, as Eucken writes, "economic reality" (wirtschaftliche Wirklichkeit) of crisis. ${ }^{6}$

However, it is important to note that the reconceptualization referred to the legal perspective; we could say that it was a "judicialisation" of eco-

1 For example, Nedergaar, P., 2018, An Ordoliberal Theory of the State, German Politics, DOI: 10.1080/09644008.2018.1514598; Cerny, P. G., 2016, In the Shadow of Ordoliberalism, ERIS, Vol. 3, Issue 1, pp. 78-91; Herrera Anchustegui, I., 2015, Competition Law through an Ordoliberal Lens, Oslo Law Review, 2, pp. 139-174; Müller, M. H.-P., 2019, Neo-Ordoliberalismus, Springer; Fèvre, R., 2017, Le marché sans pouvoir: au cœur du discours ordolibéral, Revue déconomie politique, 127(1), pp. 119-151; Hien J., Joerges, C., (eds.), 2017, Ordoliberalism, Law and the Rule of Economics, Hart Publishing.

2 More on ordoliberalism, Lošonc, A., 2018, Evropska Unija i tehnokratsko starateljstvo, Theoria, 61 (2) pp. 7-23. A. Lošonc, Depolitizacija ustavnosti: uticaj ordoliberalizma na razumevanje (evropske) ustavnosti, in: Đorđević, B., (ed.), 2018, Konstitucionalizam i ustavni dizajn u demokratskoj recesiji, Beograd, str. 67-87.

3 Gerber, D. J., 1994, Constitutionalizing the Economy: German Neo-liberals, Competition Law and the 'New Europe', American Journal of Competition Law, 42, pp. 25-84.

4 Hien, J., Joerges C., 2018, Dead man walking: Current European interest in the ordoliberal tradition, EUI Working Paper LAW 2018/3, Department of Law (https:// cadmus.eui.eu/bitstream/handle/1814/51226/LAW_2018_03.pdf?sequence=1\&isAllowed=y, 21. 9. 2019).

5 On different phases, Beaud, O., Préface, Carl Schmitt ou la juriste engage, in: Schmitt, C., 1989, Théorie de la Constitution, Paris, Puf, p. 95.

6 Eucken, W., Die grundlagen der Nationalokonomie, Enzyklopadie der Rechts- und Staatswissenschaft, Berlin, Heidelberg, Springer-Verlag, 1959 (1939), IX. 
nomics. In such a volatile period, jurists like Herman Heller, Hugo Sintzheimer and Carl Schmitt played a major role in conceptualizing the legal discourse $^{7}$ in the context of regulatory deficits: ordoliberals, who offered synergies with law and economics, promoted the constitutional role of law in order and suggested reversal for the civilization crisis, are an organic part of the same period. The ambition of the ordoliberals is a profound reform, but also an articulation of a new model of reflection which offers the transformation of collective organization of life based on the framing capacities of law. In spite of different theoretical profiles of ordoliberalism (there are even such theories that classify ordoliberalism as political theory of society ${ }^{8}$ ), our intention here is to emphasize ordoliberalism as a particular type of legal theory, but with significant meta-legal aspects.

This creates an orientation that is sometimes called Freiburg-school, sometimes ordoliberalism, ${ }^{9}$ but we also recognize another commonly used term, the "social market economy". There is also an expression "third way" in the sense that this is now the search for a new path between the laissez-faire economy and the socialist articulation of organized capitalism. As early as 1936, the Ordo Manifesto ${ }^{10}$ was written, but ordoliberalism became extraordinarily influential only after World War II in the context of German reconstruction. ${ }^{11}$ Instead of a figure of an elite-minded jurist who replicates on the crisis to save a dilapidated order, there is now a prospective jurist who directs the paths based on the consolidation and instructs the emerging politics in accordance with his normative ideas. Thus, the personality of an ordoliberal merges the roles of a theorist who conceives legal discourse and the advisor, too-the influential intellectual who contemplates the possibilities of political as well as civilizational consolidation.

7 Nörr, K. W., 1996, Eine Symbiose auf Distanz: Soziale Marktwirtschaft und Rechtsordnung in Deutschland, Sozialistische Marktwirtschaft-Soziale Marktwirtschaft: Theorie und Ethik der Wirtschaftsforschung in China und Deutschland. Heidelberg: Physica; Nörr, K.W., 1995, Franz Bohm, ein Wegbereiter des Privatrechtsgedankens, Ordo, 46, pp. 27-39.

8 This was stated by one of the most significant representatives of later generations of ordoliberalism, Wiethölter, R., Wirtschaftsrecht, in: Görlitz, A., (ed.), 1972, Handlexikon zur Rechtswissenschaft, Ehrenwirth, pp. 531-538. See: Hien J., Joerges, C., (eds.), 2017, Ordoliberalism, Law and the Rule of Economics, Hart Publishing.

9 We use this term everywhere.

10 Böhm, F., Eucken, W., Grossmann-Doerth, H., The Ordo Manifesto of 1936 in: Peacock, A., Willgerodt, H., (eds.), 1989, Germany's Social Market Economy: Origins and Evolution, Basingstoke/London, Macmillan, pp. 15-26; Böhm, F., Die außerstaatliche ('natürliche') Gesetzmäßigkeit des wettbewerblichen Wirtschaftsprozesses, in: Stützel, W., Watrin, C. Willgerodt, H. and Hohmann K. (eds.), 1981, Grundtexte zur Sozialen Marktwirtschaft: Zeugnisse aus zweihundert Jahren ordnungspolitischer Diskussion, Fischer Verlag, [1936], pp. 135-142.

11 Vanberg, V., 2008, Wettbewerb und Regelordnung, Tübingen, Mohr Siebeck, p. 48. 
In fact, the narrative about the influence of ordoliberalism divides into two directions: the first direction addresses the German situation and it manifests itself immediately after World War II. The second direction is related to the emerging European Union, starting from the 1950s when the realization of the EU began. Today, both directions often merge due to the fascination with the influence of ordoliberalism on European self-understanding.

Those studying the influence of ordoliberalism find themselves in a contradictory position and weighing seems as almost endless. On the one hand, the task is relatively easy, almost exhausting in stating mere philological information. On the other hand, the task is enormously difficult because the influence of certain ideas is never unilinear; it is never just a simple implementation of an ideational machine as much as a situation-positioning of certain ideas in a complex space of different ideational flows directed towards hegemonic positions. The exaggerated ease of validating certain forms of influence should be a warning that one must be cautious about considering other influences.

So, on the one hand, it could be just enough to point out a rich personal history of ordoliberalism in legal science, ${ }^{12}$ as well as to list those persons who were influenced by ordoliberalism. Thus, German chancellor Ludwig Erhard was a supporter of ordoliberalism and he even mediated the ideas in question, and the chief German negotiator in Rome (1957) was the aforementioned Alfred Müller-Armack; Hans von der Groeben, a civil servant of the Erhard administration, among others, was the first Director General for Competition in the European Commission. ${ }^{13}$ In addition, it would be worthwhile to point out that those who have largely shaped the policies of the European Central Bank (Jens Weidman, for example, who at the time of writing of this text did not become the ECB's

12 We just need to mention some names such as Walter Hallenstein, Kurt Biedenkopf or Ernst-Joachim Mestmäcker (who was Franz Böhm's student) who represented the second or the third generation of ordoliberals, for example, Mestmäcker, E.-J., 1990, Wirtschaftsrecht, Rabels Zeitschrift für ausländisches und internationales Privatrecht, 54. Jahrg., H. 3, pp. 409-430.

13 Wegmann, M., 2008, Neoliberalismus auf das Europäische Wettbewerbsrecht 1946 1965, Nomos; Mayer, F. C., 2000, Kompetenzüberschreitung und Letztentscheidung. Das Maastricht-Urteil des Bundesverfassungsgerichts und die Letztentscheidung über Ultra-vires-Akte in Mehrebenensystemen; eine rechtsvergleichende Betrachtung von Konflikten zwischen Gerichten am Beispiel der EU und der USA, C.H. Beck. We know that Maastricht alarmed the public in Germany, Joerges, C., 1997, States without a Market? Comments on the German Constitutional Court's Maastricht-Judgment and a Plea for Interdisciplinary Discourses, European Integration online Papers (EIoP), European Community Studies Association Austria (ECSA-A), Vol. 1, November, (http:// eiop.or.at/eiop/texte/1997-020.htm, 22. 9. 2017). 
first man) made a straightforward acknowledgement of their own ordoliberal heritage. The current German chancellor was in Freiburg two years ago when she declared standard loyalty of German politics to ordoliberalism. So, if we take this path, the reconstruction of ordoliberalism would be exhausted simply by personal reconstructions of historical roles.

However, the dissemination of ordoliberalism has always encountered opponents, that is, obstacles. There was also a crisis of recognition of ordoliberalism. For example, inflexible attitude towards certain structural aspects of the market, and an attempt to implement an order that was rigorous not only towards the state but private power on the market as well, caused dissatisfaction with US policy interested in the penetration of US firms into European market. As for the travaux préparatoires relating to EU, ordoliberals with their "third way" and negative attitude towards state interference were often in conflict with the French concept of industrial politics, which contained the elements of "dirigisme", and this brought some interpretations that EU was the fruit of an unstable compromise between ordoliberalism and dirigism. ${ }^{14}$ However, despite all the tensions and bumpy road, significant traces of ordoliberalism can hardly be denied regarding the practice of the European Court of Justice and general treatment of the law of competition: for example, some jurists have been arguing whether the Article 82 of EC Treaty is the definitive example of ordoliberal triumph. ${ }^{15}$

Yet it is true that ordoliberalism was forgotten in the 1970s. Furthermore, Maastricht and the attribution of certain intervention competencies to the ECB did not suit ordoliberals, ${ }^{16}$ again inter alia. While some interpreters emphasize the irreversible impact of ordoliberalism on European self-understanding, most notably on legally mediated integration, and even on institutional solutions within the EU, others suggest extreme caution when weighing the facts. Thus, some interpreters argue that the sui generis-form of constitutionalization, the fact that economic rules in EU are postulated "beyond political determination", can be deduced precisely from the unambiguous dominance of ordoliberal ideas. What ordoliberals

14 Warlhouzet, L., (https://blogs.lse.ac.uk/europpblog/2019/02/04/the-eu-as-an-evolving-compromise-between-french-dirigism-and-german-ordoliberalism/).

15 Akman, P., 2009, Searching for the Long-Lost Soul of Article 82EC, Oxford Journal of Legal Studies, 29(2), pp. 267-303; Talbot, C., 2016, Ordoliberalism and Balancing Competition Goals in the Development of the European Union, The Antitrust Bulletin, 61(2), pp. 264-289; Gormsen, L. L., 2007, The conflict between economic freedom and consumer welfare in the modernisation of article $82 \mathrm{EC}$, European Competition Journal, 2, pp. 329-344.

16 Streit, M. E., Mussler, W., 1995, The Economic Constitution of the European Community. From "Rome" to "Maastricht", European Law Journal, 1, pp. 5-30. 
failed to accomplish in (West) Germany they succeeded in the EU on a European ground with a mix of economic and juridic constitutionalization. ${ }^{17}$ Some other notable scholars, such as Christian Joerges who claim that "the specters of ordoliberalism are haunting Europe" emphasize that European institutions have suffered a far greater impact from Anglo-Saxon ideas. Accordingly, ordoliberalization of Europe is just one tendency among many and we can discuss only about indirect influences, and de-ordoliberalization of Europe should be considered as well.

\section{The Intensification of the Discussion OF THE ORDOLIBERALISM}

In spite of all the heterogeneous interpretations, the discussions about ordoliberalism have definitely multiplied in recent decades. The following reasons explain the situation:

1. a) the sophistication of ordoliberalism that succeeded in building new discursive frameworks to articulate essential issues that go beyond the narrow disciplinary frameworks; despite the difficulties, ordoliberalism established itself as a relevant point of reference even with regard to the legal regulation ${ }^{18}$ of the relationship between globalization and competition;

b) the power of renewal; different generations have embraced the ideas about the necessity of modernization of certain principles of ordoliberalism as evidenced in the continued activity of the annual journal Ordo.

2. a) Ordoliberalism became particularly relevant in the midst of the European crisis when many were keenly seeking a way out of crisis processes and searching for the explanations for regression processes in Europe. Various interpretations present ordoliberalism as a reservoir of ideas for a rigorous, uncompromising (German) attitude about austerity as a counter-crisis mechanism.

b) ordoliberalism is thematized as a conceptual framework for discussion about critical consideration of the constitutionalization in the EU; it can be recognized in the indeterminacy of constitution-

17 Scharpf, F. W., 2017, De-constitutionalisation and majority rule: A democratic vision for Europe, European Law Journal, 23, pp. 315-334. In accordance with this, in postwar Germany, ordoliberals were less successful in the realization of the ideas about constitutional law; their success was evident in private and economic law.

18 Gerber, D. J., 2010, Global Competition: Law, Markets, and Globalization, Oxford University Press. 
ality in the EU, repeated debates about whether "integration by law" constitutes an adequate cohesive framework for the EU, and discussions about whether Europe needs a constitution at all, ${ }^{19}$

c) ordoliberalism is considered (a "kind of Napoleonic self-coronation" $^{20}$ ) in relation to the postulated constitutional court functions of European Court of Justice,

d) ordoliberalism is immanently present in the considerations of strategic position of Germany in EU.

To summarize: ordoliberalism is a rehabilitated but contested concept as well in the midst of European crisis.

\section{Implicit Constitutionalization BY ORDO-ECONOMY?}

The key indications for ordoliberalism are: "economic constitution" and "ordo of the economy is a legal order" (Wirtschaftsordnung ist Rechtsverfassung); "The legal order as an order of freedom" ("Freiheitsordnung").

All three projections are related to representative jurist Franz Böhm. However, the term "economic constitution" does not originate from him; the mentioned prominent jurist just interpreted the term for the purposes of ordoliberalism, though with a dose of originality. Namely, it can be said that it is a genuinely German term despite the fact that the syntagm "economic constitution" is not supported by the Roman law, the Law of the Church, or the Natural Law School. Moreover, the term was not even supported in Pandectistics, but it developed only after 1919, that is, in a turbulent period after the defeat in World War I. It seems that the mentioned Sinzheimer used the term first in relation to the economic councils. ${ }^{21}$ Böhm, despite propagating a "strong state", decisively separates the reconceptualized form of constitutionality from the state and links it to the economic dynamics of market competition. In doing so, he promotes private law as the basis for social integration, and defines the state as the supreme "guardian" of economic order. Thus, the concept of "economic order as legal order" results from the perspective of private law: private law and economic law have become benchmark for the macro-articulations of collective economic life. Or, as Mestmäcker lapidarily says, "economic law

19 Dullien, S., Guérot, U., 2012, The Long Shadow of Ordoliberalism: Germany's Approach to the Euro Crisis, European Council on Foreign Relations Policy Brief 22.

20 Tuori, K., 2017, European Constitutionalism, Cambridge University Press. p. 137.

21 For broad historical explanation, Nörr, K. W., 1994-1995, Economic Constitution: On the Roots of a Legal Concept, Journal of Law and Religion, 11(1), pp. 343-354. 
is the law of economic orders". 22 Walter Eucken also talks about the "basic principles of order" (Ordnungsgrundsätze), which actually means law-mediated framing of "economic order"23: in other words "economic order" is the result of "economic constitution" (Wirtschaftsverfassung).

This generates circumstances that change the coordinates of both legal and economic discourse, creating the basis for the subsequent constitutionalization of economic flows within the EU, as well as the conditions for adjusting the relations between economic and juridic constitutionalization in Europe. In other words, the conditions for the Europeanisation of ordoliberalism are created, that is, for the empowerment of the logic of Wirtschaftsverfassung on European soil ${ }^{24}$ (some interpreters propose ordoliberal extension of economic constitution onto the global level ${ }^{25}$ ). We should only remember the classic case of Van Gend en Loos which, with its legal framework, had a robust objective: advancing the economic order of the common market.

As for the term "ordo" (whose unambiguous translation is almost impossible), the situation is much different. Namely, the said term (formally) refers to a set of elements that make up a well-articulated whole and it has an extremely long premodern and religious history. We could cite different forms of usage of the term ranging from "ordo iuris" to "ordo digestorum". 26 There are parallel usages as well: Carl Schmitt, for example, who otherwise followed other paths than the ordoliberals, used the term conclusively in his writings, seeking opportunities between voluntarist decisionism and abstract normativism, that is, rejecting abstractly postulated Sollen in relation to legal institutions. In doing so, he particularly emphasized the notion of "concrete order" pointing out that norms and rules were embedded in "frames and ground of a given order". ${ }^{27} \mathrm{We}$ should also mention other meanings of order that emphasize the problem of continuity and change, the necessity for autonomous social agents to

22 Mestmäcker, E.-J., 2012, Wettbewerbsfreiheit und Wohlfahrt, ORDO: Jahrbuch für die Ordnung von Wirtschaft und Gesellschaft, 63, pp. 410.

23 Eucken, W., 1959, Die Grundlagen der Nationalokonomie, Enzyklopadie der Rechtsund Staatswissenschaft, Springer-Verlag, Berlin heidelberg (1939), IX, p. 52.

24 Müller-Armack, A., 1966, Die Wirtschaftsordnung des Gemeinsamen Marktes, in: Wirtschaftsordnung und Wirtschaftspolitik. Studien und Konzepte zur sozialen Marktwirtschaft und zur europäischen Integration, Rombach, pp. 401-415.

25 Behrens, P., 2000, Weltwirtschaftsverfassung, Jahrbuch für Neue Politische Ökonomie, 19.

26 Böckenförde, E. W., 2017, Ordnungdenken, in: Ritter, J., (ed.), Historisches Wörterbuch der Philosophie, 1971-2007, Schwabe Verlag, Basel, und Lizenzausgabe für die Wissenschaftliche Buchgesellschaft, Darmstadt, pp. 13148-13149.

27 Schmitt, C., 1935, Über die drei Arten des rechtswissenschaftlichen Denkens, Berlin, Duncker \& Humblot, pp. 10-20. 
act by the logic of coordination, as well as the fact that order is always an "undetermined" process. ${ }^{28}$ Ordoliberals have always paid great attention to the problems of order regarding the simultaneity of autonomy and coordination of different activities, but they were skeptical about the ideas to divide abstract concepts of market into non-predetermined processes.

Schmitt's notion of "concrete order" with a significant conceptual status in his legal philosophy has, despite all the differences, common grounds with ordoliberal concepts. Namely, ordoliberals also seek the possibility of embeddedness of the economy but in relation to the legally enframed order. It should be added that the ordoliberal notion of embeddedness also shows clear religious aspects that have formed strong opinions about law and economics: in fact, the ordoliberal concepts were developed from the Protestant-Lutheran tradition. ${ }^{29}$ Furthermore, Schmitt shares something else with ordoliberals. ${ }^{30}$ Namely, both he and ordoliberals promote a certain kind of "comprehensive decision" (Gesamtentscheidung). ${ }^{31}$ Eucken interprets the term (which was already used with references to Schmitt by Böhm in the aforementioned part) as a sort of general "decision" 32 in relation to "economic life", in other words, "economic constitution" is nothing more than an expression of the said form of constitutive decision of those who decided to live a common life in a certain way. Tuori, who analyzes the ECJ legal practice in the perspective of ordoliberal microeconomization of juridical constitutionalism, recognizes here some problems regarding the relationship between constitutional law and constitution as such. ${ }^{33}$ However, the creation of norms from an ordoliberal perspective is a general problem.

We agree with Tuori that the spotlight falls on the fact that it is not necessary for a "comprehensive decision" to crystallize into a formally framed constitution. Thus, it can be said in a certain way that the Treaty of Rome from the ordoliberal point of view is precisely the expression of a substantive constitution. Accordingly, we are talking about "implicit constitutionality".

28 Spengler, J. J., 1948, The Problem of Order in Economic Affairs, Southern Economic Journal, XV(1), pp. 1-29; Samuels, W., Joseph J., Spengler's Concept of the 'Problem of Order': A Reconsideration and Extension, in: Arestis, P., (ed.), 1996, Employment, Economic Growth and the Tyranny of the Market, pp. 185-99.

29 Manow, P., 2001, Ordoliberalismus als ökonomische Ordnungstheologie, Leviathan, 29(2), pp. 179-198; Krarup, T., 2019, German Political and Economic Ideology in the Twentieth Century and its Theological Problems: The Lutheran Genealogy of Ordoliberalism, European Journal of Cultural and Political Sociology, 6(3), pp. 317-342. (https://doi.org/10.1080/23254823.2018.1559745).

30 Nörr, Nörr, K. W., 1994-1995, Economic Constitution: On the Roots of a Legal Concept, Journal of Law and Religion, 11(1), p. 350.

31 Tuori, K., 2017, European Constitutionalism, Cambridge University Press, p. 131.

32 Eucken, W., 1959, p. 52.

33 Tuori, K., 2017, p. 133. This difference Schmitt also insists on. 
It is a substantive, not a formal decision regarding the ordoliberal realization of legal norms: "economic constitution" is beyond formal constitutionalization and it expresses a decision that has guiding substantive aspects - in relation to ordoliberals, it is an expression of collective engagement with respect to market and given economic order, or more to "legal-economic-nexus" of the market determined by competition. Substantive constitutionalism was entrusted with the task of defending competition on the market from various deformations, that is, maintaining competition as an autotelic principle. Part of this is dissatisfaction with classical liberalism, which, despite its efforts, cannot understand society as a set of different orders ("interdependence of orders") and which mistakenly isolates the economy from law and politics. It is not a coincidence that when Böhm mentions Gesamtentscheidung he makes reference to a political constitution as well.

We have said that the Treaty of Rome can, to some extent only, be accepted as an expression of substantive constitutionality in terms of ordoliberal understanding. Namely, the legal framing proposed by ordoliberalism implies a holistically full picture of economic order: it is not merely abstract turning to competition on the market as much as a specific economic model with an ideological affirmation of a given orientation. Ordoliberals, however, also draw on certain elements of general market theory, but at the same time they invoke various specific aspects as well: for example, Ordoliberal skepticism and criticism of the welfare state in postwar Germany and Europe are marked with an interpretative model that argued versus some accepted (welfare) standards at the time. The notion that the "market economy" is per se "social" (and is not to be socialized) represents a specified concept of the market.

Duncan Kennedy proposes a threefold classification of the globalization of law: he distinguished the rise of "classical legal thought" by the beginning of 1914; from 1914 to the end of the 1960s, the law was embroiled in the articulation of "social moment"; after 1945, a process of neo-formalization and adjuration developed. ${ }^{34}$ If we accept this classification, then ordoliberals, undoubtedly, belong to the second period offering a market articulation of social momentum. Unlike many other (neo) liberals, who were reluctant to use the adjective "social", ordoliberals tried to explain the "social moment", but this also entailed a special concept not only of the market but also of the collective organization of life, which ordoliberals never denied.

However, if we discuss the affirmation of such, special, interpretation of market economy, then it must be problematized. Justice Holmes (from the perspective of the USA), who expressed dissent in famous Lochner-case

34 Kennedy, D., Three Globalizations of Law and Legal Thought: 1850-2000, in: Trubek, D. M., Santos A., (eds.), 2006, The new law and economic development, 19, pp. 25-71. 
(criticizing "lochnerism"), explained his decision by presenting the argument that constitution should not reflect the premise of certain economic theory that supports particular type of economic transaction as an undeniable core of constitution. ${ }^{35}$ Furthermore, in Germany as well, The Constitutional Court has the same attitude towards Investitionshilfegesetz as towards the Basic Law. ${ }^{36}$ It is notable that, for a long time, the EU has not made a decisive statement regarding the articulation of the essential pillars of the European economy: we should not forget that during the preparation period, the "drafters" even predicted the possibility of presenting socialist view of property and emphasized a marked neutrality on the "property regime". ${ }^{37}$ This is completely opposite of the ordoliberal understanding of economization that treats private property as an expression of Grundsatz. Ordoliberals could have been satisfied only after offensive articsulation personalized by Jacques Delor's in the 1980s, who offered a happy synthesis between social sensitivity and neoliberalism, but then, as we said earlier, ordoliberalism was already in a shadow. The problem remains that "lochnerism", or the imposition of a specific economic model, also affects ordoliberalism, that is, the constitutionalization of certain type of economic order. This could mean that ordoliberals had to change the concept of constitutionality for the purpose of affirmation of their position.

Furthermore, we disagree with the statement that involves Hans Kelsen and his concept of Grundnorm: according to this, "economic constitution" derives from Kelsen's determining concept. ${ }^{38}$ However, it is hard to accept that ordoliberals followed Kelsen's steps because at that time he was completely forgotten in Germany. ${ }^{39}$ Even though some parallels between identification of state and law can be discovered, or Rechtsordnung (legal system) in Kelsen and Rechstaat with ordoliberals, it is not the basis for discussion about analogy. Ordoliberals have doubts regarding Kelsen's definition of law as "certain order or organisation of power" and articulation of Grundnorm that can lead to different, insecure outcomes, thus supporting planned economies as well. ${ }^{40}$ Kelsen's adherence to state prac-

35 Detailed about it, Purdy, J., 2015, Neoliberal constitutionalism: lochnerism for a new economy, Law and Contemporary Problems, 77, pp. 195-213, (https://scholarship.law. duke.edu/cgi/viewcontent.cgi? article $=4713 \&$ context $=$ lcp).

36 Tuori, K., 2017, p. 136.

37 Akkermans, B., Ramaekers, E., 2010, Article 345 TFEU (ex Article 295 EC), its meanings and interpretations, European Law Journal, 16(3), pp. 292-314.

38 Felice, F., Vatiero, M., 2014, Ordo and European Competition Law, Research in the History of Economic Thought and Methodology, in: A Research Annual, volume 32, Emerald Publishing Ltd, pp. 147-157.

39 Somek, A., 2006, Stateless Law: Kelsen's Conception and its Limits, Oxford Journal of Legal Studies, 26(4), Winter, pp. 753-774; Möllers, C., 2000, Staat als Argument at 125.

40 Mestmäcker, E.-J., 2007, A legal theory without law, Posner v. Hayek on Economic Analysis of Law, Mohr/Siebeck. 
tice and critical attitude towards "juridically understood" private property is contradictory to ordoliberal concept. ${ }^{41}$ We know that the norms in his work do not refer to truth but to validity. However, ordoliberals are not familiar with positivistic cognition of law and related legal epistemology. Positivistic Kelsen regards law as an order of coercion, but explains it as validity ${ }^{42}$ behind which there is only contingent human will, which reductively formalizes the question of validity of legal norms: in reality, this is the way ordoliberals criticized Kelsen. Besides, ordoliberals would not be satisfied with the lack of meta-legal aspects or substantive criteria in the work of Reine Rechtslehre. Finally, in Kelsen's work, Grundnorm is based on positive law: "economic constitution" is, however, also determined by habitualized norms of established economic communication.

So, how can "economic constitution" be assessed? Günther Teubner, who thematized the possibility of transnational economic constitution, expressed the opinion that, in contrast to Kelsen, ordoliberals affirmed economic constitution from the perspective of formal-legal hierarchy of norms with economic content. He suggests the term "double reflexivity" as a crucial moment in explanation; therefore, the specificity of ordoliberalism lies in the fact that it has developed a constant systematic connection between basic institutions of economic order and constitutional norms. ${ }^{43}$ Teubner expresses this view in terms of praise: nevertheless, we would like to warn about lochnerism as a phenomenon of legal-economic nexus.

\section{Economization of Ordoliberal Concept of Competition?}

Focusing on competition as a holistic feature of order and as a subjective law also implies a critical attitude towards private forms of power that have emerged on the market. The competition (which is "perfor-

41 Römer, P., Die Kritik Hans Kelsens an der juristischen Eigentumsideologie, in: Krawietz, W., Topitsch, E., Koller, P. (Hg.), 1982, Rechtstheorie. Beiheft 4: Ideologiekritik und Demokratietheorie bei Hans Kelsen, Berlin.

42 With regard to the assessment of validity of norms in Kelsen, Raz, J., 1979, The Authority of Law, Oxford University Press, p. 125. Mestmäcker distinguishes between the legal theory on validity of legal norms and legal philosophy relating to the possibilities of founding law-based norms. Mestmäcker, E.-J., 2008, A Legal Theory Without Law - Posner v. Hayek on Economic Analysis of Law, (SSRN: https://ssrn.com/ abstract=1168422 or http://dx.doi.org/10.2139/ssrn.1168422).

43 Teubner, G., 2014, Transnationale Wirtschaftsverfassung: Franz Böhm und Hugo Sinzheimer jenseits des Nationalstaates, Zeitschrift für ausländisches, öffentliches Recht, 74, pp. 733-761. 
mance" and "preventive-biased" 44 or "as if" 45 ) plays a specific role in formulating the concept of the totality by ordoliberals. Simultaneously, there is no competition without order, that is, competition must be embedded. Furthermore, it is the economic constitution only that can ensure stability of order which is based on rule-based competition. The state is requested to change or eliminate the power modes in question for the purpose of reproducing the whole: instead of intervention, the state should ensure stability of competition-based order, "strong state" is the one that ensures stability. Ordoliberals forecast "competition authority" which should be neutral enough (with respect to the state as well) to provide "undistorted competition" based on the correction of market power.

Historically, German legal heritage and forms of cartel regulation, that is, cartel law, ${ }^{46}$ were also present. It would also be appropriate to mention here the intense debate about the influence of (possible) general prohibition of abuse of dominant position on the market in the last fifty years of the $20^{\text {th }}$ century which extends to the discussions of the present day - let us not forget, for example, the investigation initiated by German authorities regarding the abuse of dominant position in the context of Facebook. ${ }^{47}$ Ordoliberals traditionally attack cartels and corporations that act

44 Performance competition is connected to the classical competitive advantage, preventive competition can be negatively defined as a way of disabling rivals, Gerber, Gerber, D. J., 2010, Global Competition: Law, Markets, and Globalization, Oxford University Press, 113.

45 As if competition means that the one who has market power should act as if there is effective competition, the concept was introduced by Leonhard Miksch. Although some interpreters believe that this impractical concept (Anchustegui, H. I., 2015, Competition Law through an Ordoliberal Lens, Oslo Law Review, 2) this term should be analyzed in analogy with the concept of Vaihinger, H., 1922, Die Philosophie des Als $O b$, Leipzig, Felix Meiner Verlag. Here, we do not have the opportunity to refer to the understanding of competition as discovery-procedure with Hayek who finished his career in Freiburg, Hayek, F. von, 1972, Die Theorie komplexer Phänomene, JCB Mohr.

46 Nörr, K. W., 1957, Law and Market Organization: The Historical Experience in Germany From 1900 to the Law Against Restraints of Competition (1957), Journal of Institutional and Theoretical Economics (JITE)/Zeitschrift für die gesamte Staatswissenschaft, Vol. 151, No. 1, The New Institutional Economics Market Organization and Market Behavior (Mar. 1995), pp. 5-20.

47 Behrens, P., 2015, The ordoliberal concept of "abuse" of a dominant position and its impact on Article 102 TFEU (https://www.econstor.eu/bitstream/10419/120873/1/834998815. pdf). Different French and German concepts of 'abuse' should be considered, Joliet, R., 1970, Monopolization and Abuse of Dominant Position. A Comparative Study of the American and European Approaches to the Control of Economic Power; Mestmäcker, E.-J., 1972, Concentration and Competition in the EEC, Part I, Journal of World Trade Law, pp. 615-647. As we already know, Article 102 TFEU contains the list of abusive behavior. Gerbrandy, A., 2019, Rethinking Competition Law within the European Economic Constitution, JCMS, 57(1), pp. 127-142. 
as sources of law, questioning whether the spontaneous market processes would lead to desirable results, that is, believing that such processes would create such cumulation of power that derogates competition. The belief that ordoliberals are directed to legal and systematic exercise of power ${ }^{48}$ is accurate: it explains their interest in competition law that should provide legal articulation of economic order.

The already mentioned debate about the influence of ordoliberals can be additionally supported if their formulation of the European competition law is taken into account. The ordoliberals' influence on the Treaty on European Union and the Treaty on the Functioning of the European Union can be thematized in the same way as their impact on the mentioned form of law - as we already know, competition law is an immanent part of European treaties aiming at formulating the synthesis between the system of economic freedom and internal market. This is the way ordoliberals interpret the Treaty of Rome, that is, as a constellation that provides "undistorted competition". ${ }^{49}$ However, there are certain fundamental questions that limit ordoliberal reflections on competition: is the subjective law of competition basis for effective competition? Does the mentioned law relate to optimal welfare or, maybe, to consumers' welfare? Is the existence of a cartel a breach of Treaty Law? What does the following mean: "prohibition of anticompetitive arguments", "abuse of market power", "control of mergers", rules of game for the concentration on the market? What is the aim of the competition law? What is the instrument for the affirmation of competition law? ${ }^{50}$ Should the dominant position on the market be controlled or the competition protected? ${ }^{51}$

In order for us to be able to answer the questions, we have to make some comparison. Ordoliberal tendencies are often confronted with American tradition of law and economics. To be precise, Sophie Harnay and Alain Marciano distinguish two striking orientations regarding the

48 Rose, V., Bailey, D., (eds.), 2013, Bellamy \& Child: European Union Law of Competition, Oxford University Press; Akman, P., 2012, The Concept of Abuse in EU Competition Law: Law and Economic Approaches, Hart, pp. 55-105.

49 Mestmäcker, E.-J., Auf dem Wege zu einer Ordnungspolitik für Europa, in: Mestmäcker, E.-J., Möller, H., and Schwarz, H.-P., (eds.), 1987, Eine Ordnungspolitik für Europa: Festschrift für Hans von der Groeben zu seinem 80. Geburtstag, Baden-Baden: Nomos, p. 11.

50 Mestmäcker, E.-J., 2012, Wettbewerbsfreiheit und Wohlfahrt (Freedom of Competition and Welfare), ORDO: Jahrbuch für die Ordnung von Wirtschaft und Gesellschaft, 63, pp. 429-448; Max Planck Private Law Research Paper No. 12/2, (SSRN: https:// ssrn.com/abstract=1983193).

51 Boy, L., 2005, Labus de pouvoir de marché: contrôle de la domination ou protection de la concurrence?, Revue internationale de droit économique, XIX, 1, pp. 27-50. 
interaction between law and economics in the context of Chicago-school: the first is marked by Ronald Coase, the second is connected with Richard Posner. ${ }^{52}$ The first orientation is called law and economics and the second is referred to as economic analysis of law. Yet, we are not interested in reporting about the differences as much as we are interested in emphasizing the tendency towards economization of law, which implies the starting point based on which the law is inherently incomplete. This means that the law has to be internationalized but through economics. Posner openly brings into question the autonomy of legal science. ${ }^{53}$

De-autonomization of legal science has been many times interpreted as manifestation of the problem of intercontinental parochiality. Economic analysis of law was developed in America and its proprium cannot be imagined outside the mentioned continent: simultaneously, some interpreters gladly state that ordoliberalism is a true, indigenous doctrine concerning Europe. However, the reception is very heterogeneous and develops in different directions. Undoubtedly, there is criticism directed to economic analysis of law in Europe: this way, certain methodological but simultaneously internal criticisms that only seek to expand the given frame can be mentioned. ${ }^{54}$ But, more radical criticisms can be mentioned and they lament that economic analysis of law results in a regression from competition control to (reduced) competition regulation, ${ }^{55}$ which is followed by pernicious "invalidation of substrate of law". ${ }^{56}$ Some interpreters find it important to point out that, in the meantime, the European law has

52 Harnay, S., Marciano, A., 2011, Lanalyse économique du droit. Éléments de rupture et de continuité des années 1970 à aujourd'hui, Économie publique/Public economics, 26-27, 1-2, pp. 71-92. Marciano, A., 2007, Value and Exchange in Law and Economics: Buchanan versus Posner, Review of Austrian Economics, 20(2), pp. 187-200. Buchanan, J. M., 1974, Good Economics - Bad Law, Virginia L. Rev., 60, pp. $483-492$.

53 Hayek wrote in the following way: "One is sometimes tempted to ask," he said, "whether the separation of legal and economic studies was not perhaps, after all, a mistake." Hayek, F. A., 1962, The Economy, Science, and Politics, in: Studies in Philosophy, Politics and Economics, London, Routledge and Kegan Paul, 1967, p. 251. Quoted by Slobodian Q., Globalists, Harvard University Press, 2018, p. 205.

54 Backhaus, J. G., 2017, Jurists' economics versus economic analysis of law: a critique of professor Posner's "economic" approach to law by reference to a case concerning damages for loss of earning capacity, European Journal of Law and Economics, DOI 10.1007/s10657-017-9559-2; Peltzman, S., 2005, Aaron Director's Influence on Antitrust Policy, Journal of Law \& Economics, 43, p. 313.

55 Boy, L., 2005.

56 Kirat, T., Action juridique et calcul économique. Regards d'économie du droit, in Le droit dans l'action économique, dir. Th. Kirat et É. Serverin, 2000, Paris, CNRS Éditions, p. 124. 
adapted in conceptual/technical terms to the economic analysis of law, but much slower than in America. ${ }^{57}$

\section{A Position of the Ordoliberalism VIS-À-VIS LAW AND ECONOMIC}

How is ordoliberalism positioned in the mentioned reception? Has the range of its activities decreased?

The issue is exacerbated by the fact that ordoliberalism is often criticized for insufficient appreciation of economic efficiency and performances in relation to the competition law, for its metaphysical engagement or, sometimes, for alleged affirmation of "humanistic values" against the efficiency criteria. Therefore, inherently insufficient economization of ordoliberal reflection has mentioned certain representatives who should criticize doctrinally such forms of dominant position that are result of market processes, that is, their position is a combination of contingent facts and merits. Accordingly, they have been presented with an idealistic image of competition that does not comply with capitalist reality of creative destruction. Finally, the European Commission, which plays an important role in regulating the competition, has also emphasized the necessity for affirmation of "more economic approach", so it is common in its practice to apply the same principle. ${ }^{58}$ The deepening of economization imposes demands on ordoliberalism: it must show its strength again in respecting all the consequences of a "more economic approach". This way, for example, we can discuss how convenient it is for ordoliberalism in its thematization of the objectives of competition law to accept the criterion of consumer welfare, or must it be satisfied with consumer choice, given that ordoliberals typically express scepticism about consumer welfare as the ultimate criterion for the realization of law? ${ }^{59}$ Specifically, ordoliberal-

57 Garoupa, N. Updating the Law and Economics of Legal Parochialism, in: Marciano, A., Battista Ramello, G. (eds.), 2016, Law and Economics in Europe and the U.S., Springer, pp. 171-185.

58 On that, Immenga, U., Mestmäcker, E.-J., (Hrsg.), 2012, Wettbewerbsrecht Gesamtwerk - Wettbewerbsrecht, Kommentar zum europäischen Kartelsrecht, 5. Auflage, Bd. I EU Teil I Einleitung B-D. In accordance with this could we treat the next wellknown examples: ECJ Case C-95/04 British Airways v. Commission [2007] ECR, I-2331, 2411, para. 106; CFI Case T-340/03 France Télécom v. Commission [2007] ECR, II-117, 193, para. 266; CFI Case T-201/04 Microsoft v. Commission [2007] ECR, II-3601, 3824, para. 664.

59 Behrens, P., 2014, The "Consumer Choice" Paradigm in German Ordoliberalism and its Impact upon EU Competition Law, 1/14 Discussion Papers from Europa-Kolleg Hamburg. 
ism has critical attitude towards interpreters of antitrust law who believe that consumer calculus and categories of price are insurmountable horizon for competition law? ${ }^{60}$

It cannot be denied that different generations of ordoliberals have refined legal instrumentarium regarding the competition. This way, the mere existence of Platform-economy has caused inner changes in ordoliberal logic. ${ }^{61}$

However, the question remains regarding the last line of defense in terms of self-understanding of ordoliberals, that is, the question of its identity in the dynamics of adjustment. In other words, if we assume that ordoliberals are dictated by economization, then the problem arises regarding the salvation of theoretical norms. ${ }^{62}$ In one important article, ${ }^{63}$ the author, who has been quoted many times in this paper, Mestmäcker, strongly promotes affirmation of law rather than turning it into a legal theory: this is particularly directed against the Chicago-biased concept. Ordoliberalism, therefore, opposes the subsumption of law in relation to economics and does not accept the teleological operationalization of such criteria as consumer calculation in terms of competition law; it should be accepted that there is no strong, unambiguous causal relationship between regulation of competition and "welfare effects". In addition, the law develops resistance towards welfare maximalization as a supreme criterion for competition conduct. Actually, law and economics (or "visible hand of law" versus "invisible hand of market") have become different based on the way in which they understand the relationship between means and goals for organization of collective life because, according to law, the mentioned relationship is not just a "pragmatic methodological operation". Cost-benefit analysis can be an expression of "end-neutral" technic, but legal norms represent something we will call "non-end-neutrality" (independently of Mestmäcker). Wealth-maximization should not replace the inner teleology of law - otherwise, the law will become just an exegesis of criteria of economic optimality.

60 Averitt, N. W., Lande, R. H., 2007, Using the "Consumer choice" Approach to Antitrust Law, Antitrust Law Journal, 74, p. 175.

61 Hamelmann, L., Haucap, J., 2016, Wettbewerb und Kartellrecht auf Online-Plattformmärkten, ORDO - Jahrbuch für die Ordnung von Wirtschaft und Gesellschaft, 67(1), pp. 269-298.

62 Müller, C., 2015, Das Naturrecht in der Wirtschafts- und Sozialethik. Bemerkungen zu einem von Herbert Pribyl und Christian Machek herausgegebenen Tagungsband, ORDO - Jahrbuch für die Ordnung von Wirtschaft und Gesellschaft, 66, pp. 411-415.

63 Mestmäcker, E.-J., 2007, "A Legal Theory without Law," Beiträge zur Ordnungstheorie und Ordnungspolitik, Freiburg, Mohr Siebeck. 
It is the core of ordoliberalism that definitely separates it from law and economics orientation. However, the question still remains as to whether we could confirm the Solomon solution according to which ordoliberalism should prevail in terms of respecting general principles but in case of case-by-case assessment it would assimilate a "more economic approach". ${ }^{4}$ We are more prone to quoting the following statement: "In the legal-economic nexus, the law is a function of the economy, and the economy (especially its structure) is a function of law. The economy is a function of law in that law either facilitates or determines what takes place in the economy, for example, through government spending or definition and assignment of rights... the legal-economic nexus is the social process in which are (re)worked out power structure, law, distribution, and societal values and definitions." 65

Actually, this is a non-conclusive assessment in terms that it suggests indeterminacy and processuality regarding the outcome of interrelation between law and economy. However, it is parallel to ordoliberal intention to oppose to the subsumption of law. As such, it casts light on the law-based self-understanding of ordoliberalism.

\section{Conclusion}

Historical dynamics has enabled ordoliberalism to affect significantly the European self-understanding and to form legal and economic orientations of different politics. Ordoliberalism has been developed from the area that faced the crisis, it affected the framing of the EU after the WWII and the traces in question are irreversible. Although we have emphasized that the EU configuration does not reflect only ordoliberal ideas, a special attention should be devoted to the concept of order and economic constitution that has been interpreted as non-Kelsenian law-based account. Ordoliberalism is also in the context of law and economics-orientation and under the pressure of accepting "more economic approach" despite the fact that it can be problematized as an orientation that accepts certain, particular model of economics with legal consequences ("lochnerism"). Finally, due to its legal and economic dynamics, ordoliberalism is subject to adjustments, so its identity is again brought into question. In contrast

64 Anchustegui, H. I., 2015.

65 Samuels, W. with joint authorship by Buchanan, J. M., Johnson, K. D., Johnson, M., Schmid, A. A. and Shaffer, J. D. 2007, The Legal-Economic Nexus, Routledge, p. 30. We can notice that Samuels does not use the term economics as much as he uses economy. 
to the law and economic approach, ordoliberalism defends the idea of "autotelic" law that has autonomy in comparison to the quantitatively operationalized criteria of welfare. Ordoliberalism offers the possibility for reflection on the relationship between law and economics in Europe, but its further development depends on the many challenges and uncertainties.

\section{BIBLIOGRAPHY}

1. Akkermans B., Ramaekers, E., 2010, Article 345 TFEU (ex Article 295 EC), its meanings and interpretations, European Law Journal, 16(3).

2. Akman, P., 2009, Searching for the Long-Lost Soul of Article 82EC, Oxford Journal of Legal Studies, 29(2).

3. Akman, P., 2012, The Concept of Abuse in EU Competition Law: Law and Economic Approaches, Hart Publishing.

4. Averitt, N. W., Lande, R. H., 2007, Using the "Consumer choice" Approach to Antitrust Law, Antitrust Law Journal, 74.

5. Anchustegui, H. I., 2015, Competition Law through an Ordoliberal Lens, Oslo Law Review, 2.

6. Backhaus, J. G., 2017, Jurists' economics versus economic analysis of law: a critique of professor Posner's "economic" approach to law by reference to a case concerning damages for loss of earning capacity, European Journal of Law and Economics, DOI 10.1007/s10657-017-9559-2.

7. Beaud O., Préface, Carl Schmitt ou la juriste engage, in: Schmitt, C., 1989, Théorie de la Constitution, Paris Puf.

8. Behrens, P., 2014, The "Consumer Choice" Paradigm in German Ordoliberalism and its Impact upon EU Competition Law, 1/14 Discussion Papers from EuropaKolleg Hamburg.

9. Behrens, P., 2015, The ordoliberal concept of "abuse" of a dominant position and its impact on Article 102 TFEU (https://www.econstor.eu/bitstream/10419/120873/1/834998815.pdf).

10. Behrens, P., 2000, Weltwirtschaftsverfassung, Jahrbuch für Neue Politische Ökonomie, 19.

11. Boy, L., 2005, Labus de pouvoir de marché: contrôle de la domination ou protection de la concurrence?, Revue internationale de droit économique, XIX, 1.

12. Böckenförde, E. W., Ordnungdenken, in: Ritter, J. (ed.), 2017, Historisches Wörterbuch der Philosophie, Schwabe, Verlag Basel, 1971-2007. Lizenzausgabe für die Wissenschaftliche, Buchgesellschaft, Darmstadt.

13. Böhm, F., Eucken, W., Grossmann-Doerth, H., The Ordo Manifesto of 1936 in Peacock, A., Willgerodt, H. (eds.), 1989, Germany's Social Market Economy: Origins and Evolution, Basingstoke/London (Macmillan).

14. Böhm, F., Die außerstaatliche ('natürliche') Gesetzmäßigkeit des wettbewerblichen Wirtschaftsprozesses, in: Stützel, W., Watrin, C. Willgerodt, H. and Hohmann, K. (eds.), 1981, Grundtexte zur Sozialen Marktwirtschaft: Zeugnisse aus zweihundert Jahren ordnungspolitischer Diskussion, Fischer Verlag, [1936]. 
15. Buchanan, J. M., 1974, Good Economics - Bad Law, Virginia L. Rev., 60.

16. Cerny, P. G., 2016, In the Shadow of Ordoliberalism, ERIS, Vol. 3, Issue 1.

17. Dullien, S., Guérot, U., 2012, The Long Shadow of Ordoliberalism: Germany's Approach to the Euro Crisis, European Council on Foreign Relations Policy Brief 22.

18. Eucken, W., 1959, Die Grundlagen der Nationalokonomie, Enzyklopadie der Rechts- und Staatswissenschaft, Berlin Heidelberg, Springer-Verlag, (1939), IX.

19. Fèvre, R., 2017, Le marché sans pouvoir: au cœur du discours ordolibéral, Revue d'économie politique, 127(1).

20. Felice, F., Vatiero, M., 2014, Ordo and European Competition Law, Research in the History of Economic Thought and Methodology, in: A Research Annual, volume 32, Emerald Publishing Ltd.

21. Garoupa, N., 2016, Updating the Law and Economics of Legal Parochialism, in: Marciano, A., Battista Ramello, G. (eds.), Law and Economics in Europe and the U.S., Springer.

22. Gerber, D. J., 1994, Constitutionalizing the Economy: German Neo-liberals, Competition Law and the 'New Europe', American Journal of Competition Law, 42.

23. Gerber, D.J., 2010, Global Competition: Law, Markets, and Globalization, Oxford University Press.

24. Gerbrandy, A., 2019, Rethinking Competition Law within the European Economic Constitution, JCMS, 57(1).

25. Gormsen, L. L., 2007, The conflict between economic freedom and consumer welfare in the modernisation of article 82 EC, European Competition Journal, 2.

26. Hamelmann, L., Haucap, J., 2016, Wettbewerb und Kartellrecht auf Online-Plattformmärkten, ORDO - Jahrbuch für die Ordnung von Wirtschaft und Gesellschaft, $67(1)$.

27. Harnay, S., Marciano, A., 2011, Lanalyse économique du droit Éléments de rupture et de continuité des années 1970 à aujourd'hui, Économie publique/Public economics, 26-27,1-2.

28. Hayek, F. von, 1972, Die Theorie komplexer Phänomene, JCB Mohr.

29. Hien, J., Joerges, C., (eds.), 2017, Ordoliberalism, Law and the Rule of Economics, Hart Publishing.

30. Hien, J., Joerges C., 2018, Dead man walking: Current European interest in the ordoliberal tradition, EUI Working Paper LAW 2018/3, Department of Law (https://cadmus.eui.eu/bitstream/handle/1814/51226/LAW_2018_03.pdf?sequence=1\&isAllowed=y, 21. 9. 2019).

31. Immenga, U., Mestmäcker, E.-J., (eds.), 2012, Wettbewerbsrecht Gesamtwerk Wettbewerbsrecht, Kommentar zum europäischen Kartellsrecht, 5. Auflage, Bd. I EU Teil I Einleitung B-D.

32. Joerges, C., 1996, States without a Market? Comments on the German Constitutional Court's Maastricht-Judgment and a Plea for Interdisciplinary Discourses, (http://eiop.or.at/eiop/texte/1997-020.htm, 22. 9. 2017).

33. Joliet, R., 1970, Monopolization and Abuse of Dominant Position. A Comparative Study of the American and European Approaches to the Control of Economic Power. 
34. Kennedy, D., 2006, Three Globalizations of Law and Legal Thought: 1850-2000, in: Trubek, D. M., Santos, A. (eds.), The new law and economic development, 19.

35. Krarup, T., 2019, German Political and Economic Ideology in the Twentieth Century and its Theological Problems: The Lutheran Genealogy of Ordoliberalism, European Journal of Cultural and Political Sociology, 6(3), (https://doi.org/10.1080 /23254823.2018.1559745)

36. Kirat, T., 2001, Action juridique et calcul économique. Regards d'économie du droit, in Th. Kirat et É. Serverin (dir.), Le droit dans l'action économique, Revue internationale de droit compare, 53-4 Paris, CNRS Éditions.

37. Lošonc, A., 2018, Evropska Unija i tehnokratsko starateljstvo, Theoria, 61 (2).

38. Lošonc, A., Depolitizacija ustavnosti: uticaj ordoliberalizma na razumevanje (evropske) ustavnosti, in: Đorđević, B. (ed.), 2018, Konstitucionalizam i ustavni dizajn u demokratskoj recesiji, Beograd, Fakultet političkih nauka.

39. Manow, P., 2001, Ordoliberalismus als ökonomische Ordnungstheologie, Leviathan, 29(2).

40. Marciano, A., 2007, Value and Exchange in Law and Economics: Buchanan versus Posner, Review of Austrian Economics, 20(2).

41. Mayer, F. C., 2000, Kompetenzüberschreitung und Letztentscheidung. Das Maastricht-Urteil des Bundesverfassungsgerichts und die Letztentscheidung über Ultravires-Akte in Mehrebenensystemen; eine rechtsvergleichende Betrachtung von Konflikten zwischen Gerichten am Beispiel der EU und der USA, C.H. Beck.

42. Mestmäcker, E.-J., 2008, A Legal Theory Without Law - Posner v. Hayek on Economic Analysis of Law, (SSRN: https://ssrn.com/abstract=1168422 or http://dx.doi. org/10.2139/ssrn.1168422).

43. Mestmäcker, E.-J., 1972, Concentration and Competition in the EEC, Part I, Journal of World Trade Law.

44. Mestmäcker, E.-J., Auf dem Wege zu einer Ordnungspolitik für Europa, in: Mestmäcker, E.-J., Möller, H., Schwarz, H.-P. (eds.), 1987, Eine Ordnungspolitik für Europa: Festschrift für Hans von der Groeben zu seinem 80. Geburtstag, BadenBaden, Nomos.

45. Mestmäcker, E.-J., 1990, Wirtschaftsrecht, Rabels Zeitschrift für ausländisches und internationales Privatrecht, 54. Jahrg., H. 3.

46. Mestmäcker, E.-J., 2012, Wettbewerbsfreiheit und Wohlfahrt (Freedom of Competition and Welfare), ORDO: Jahrbuch für die Ordnung von Wirtschaft und Gesellschaft, 63; Max Planck Private Law Research Paper No. 12/2. Available at SSRN: https://ssrn.com/abstract=1983193.

47. Möllers, C., 2000, Staat als Argument, C.H. Beck Verlag.

48. Müller, M. H.-P., 2019, Neo-Ordoliberalismus, Springer.

49. Müller-Armack, A., Die Wirtschaftsordnung des Gemeinsamen Marktes, in: Wirtschaftsordnung und Wirtschaftspolitik. Studien und Konzepte zur sozialen Marktwirtschaft und zur europäischen Integration, 1966, Rombach.

50. Müller, C., 2015, Das Naturrecht in der Wirtschafts- und Sozialethik. Bemerkungen zu einem von Herbert Pribyl und Christian Machek herausgegebenen Tagungsband, ORDO - Jahrbuch für die Ordnung von Wirtschaft und Gesellschaft, 66. 
51. Nedergaard, P., 2018, An Ordoliberal Theory of the State, German Politics, 28(1), (https://doi.org/10.1080/09644008.2018.1514598).

52. Nörr, K. W., 1996, Eine Symbiose auf Distanz: Soziale Marktwirtschaft und Rechtsordnung in Deutschland, Sozialistische Marktwirtschaft-Soziale Marktwirtschaft: Theorie und Ethik der Wirtschaftsforschung in China und Deutschland. Heidelberg: Physica.

53. Nörr, K. W., 1957, Law and Market Organization: The Historical Experience in Germany From 1900 to the Law Against Restraints of Competition, Journal of Institutional and Theoretical Economics (JITE) / Zeitschrift für die gesamte Staatswissenschaft, Vol. 151, No. 1, The New Institutional Economics Market Organization and Market Behavior (Mar. 1995).

54. Nörr, K. W., 1994-1995, Economic Constitution: On the Roots of a Legal Concept, Journal of Law and Religion, 11(1).

55. Nörr, K. W., 1995, Franz Böhm, ein Wegbereiter des Privatrechtsgedankens, Ordo, 46.

56. Peltzman, S., 2005, Aaron Director's Influence on Antitrust Policy, Journal of Law \& Economics, 43.

57. Purdy, J., 2015, Neoliberal constitutionalism: lochnerism for a new economy, Law and Contemporary Problems, 77, (https://scholarship.law.duke.edu/cgi/viewcontent.cgi? article $=4713 \&$ context $=\mathrm{lcp}$ ).

58. Raz, J., 1979, The Authority of Law, Oxford University Press.

59. Rose, V., Bailey, D. (eds), 2013, Bellamy \& Child: European Union Law of Competition, Oxford University Press.

60. Römer, P., Die Kritik Hans Kelsens an der juristischen Eigentumsideologie, in: Krawietz, W., Topitsch, E., Koller, P. (Hg.), 1982, Rechtstheorie. Beiheft 4: Ideologiekritik und Demokratietheorie bei Hans Kelsen, Berlin.

61. Samuels, W., Buchanan, J. M., Johnson, K. D., Johnson, M., Schmid, A. A., Shaffer, J. D. 2007, The Legal-Economic Nexus, Routledge.

62. Samuels, W., Joseph J., Spengler's Concept of the 'Problem of Order': A Reconsideration and Extension, in: Arestis, P. (ed.), 1996, Employment, Economic Growth and the Tyranny of the Market.

63. Slobodian, Q., 2018, Globalists, Harvard University Press.

64. Scharpf, F. W., 2017, De-constitutionalisation and majority rule: A democratic vision for Europe, European Law Journal, 23.

65. Schmitt, C., 1935, Über die drei Arten des rechtswissenschaftlichen Denkens, Berlin, Duncker \& Humblot.

66. Somek, A., 2006, Stateless Law: Kelsen's Conception and its Limits, Oxford Journal of Legal Studies, 26(4), Winter.

67. Spengler, J. J., 1948, The Problem of Order in Economic Affairs, Southern Economic Journal, XV(1).

68. Streit, M. E., Mussler, W., 1995, The Economic Constitution of the European Community. From "Rome" to "Maastricht", European Law Journal, 1.

69. Talbot, C., 2016, Ordoliberalism and Balancing Competition Goals in the Development of the European Union, The Antitrust Bulletin, 61(2). 
70. Teubner, G., 2014, Transnationale Wirtschaftsverfassung: Franz Böhm und Hugo Sinzheimer jenseits des. Nationalstaates, Zeitschrift für, ausländisches, öffentliches Recht, 74.

71. Tuori, K., 2017, European Constitutionalism, Cambridge University Press.

72. Vaihinger, H., 1922, Die Philosophie des Als Ob, Leipzig, Felix Meiner Verlag.

73. Vanberg, V., 2008, Wettbewerb und Regelordnung, Tübingen, Mohr Siebeck.

74. Warlhouzet, L., 2019, (https://blogs.lse.ac.uk/europpblog/2019/02/04/the-eu-asan-evolving-compromise-between-french-dirigism-and-german-ordoliberalism/, 23. 10. 2019).

75. Wegmann, M., 2008, Neoliberalismus auf das Europäische Wettbewerbsrecht 19461965, Nomos.

76. Wiethölter, R., Wirtschaftsrecht, in: Görlitz, A. (ed.), 1972, Handlexikon zur Rechtswissenschaft, Ehrenwirth.

\title{
Court Decisions
}

1. ECJ Case C-95/04, British Airways v. Commission [2007] ECR, I-2331, 2411, para. 106.

2. CFI Case T-340/03, France Télécom v. Commission [2007] ECR, II-117, 193, para. 266.

3. CFI Case T-201/04, Microsoft v. Commission [2007] ECR, II-3601, 3824, para. 664.

\section{ORDOLIBERALNA ARTIKULACIJA ODNOSA IZMEĐU PRAVA I EKONOMIJE}

\author{
Alpar Lošonc \\ Sonja Bunčić \\ Andrea Ivanišević
}

REZIME

Poslednjih decenija pojavile su se različite teorije koje su se odnosile na vezu između prava i ekonomije. Uglavnom su iznikle na anglosaksonskom tlu. Međutim, ne treba zaboraviti na činjenicu da je nemački ordoliberalizam već formirao određenu i markantnu vezu povodom pomenutog odnosa. Shodno tome, može se reći da je ordoliberalizam izvesna vrsta rodonačelnika u pogledu tretiranja odnosa prava i ekonomije. Ordoliberalizam spaja intenciju u odnosu na rekonstrukciju liberalizma i rehabilitaciju pojma „ordo” koji dobija široko tumačenje u okvirima ordoliberalizma. Rad, koji sledi ordoliberalnu konceptualizaciju na pravnom terenu, sastoji se iz tri dela. Prvi deo se odnosi na kratko opisivanje 
nastanka ordoliberalizma i na prezentaciju razloga uticaja ordoliberalizma na današnju evropsku samotematizaciju. Ordoliberali polaze od krizne retorike u vajmarskom periodu Nemačke i na osnovu toga izgrađuju teoriju koja će postati relevantna posle II svetskog rata u Nemačkoj i u sklopovima Evropske unije. Drugi deo pokušava da pokaže da je pravo shvaćeno kao konstitutivna orijentacija u odnosu na „ordo“, ključna tačka ordoliberalnog projekta, te objašnjava smisao ekonomskog konstitucionalizma. Treći deo analizira značaj konkurencije u pogledu kreiranja „order" i postavlja pitanje kako se ordoliberalizam ophodi prema vezi prava i ekonomije posebno u domenu prava konkurencije. U istom delu se istražuje pitanje odbrane identiteta ordoliberalizma u kontekstu sveopšte pravne i ekonomske dinamike.

Ključne reči: ordoliberalizam, pravo i ekonomika, kriza, konstitucionalizacija, ekonomizacija.

Article History:

Received: 31 October 2019

Accepted: 28 November 2019 